\title{
МОЖЛИВОСТІ ВИКОРИСТАННЯ АНАЛІТИЧНИХ ІНСТРУМЕНТІВ ДЛЯ ПІДТРИМКИ ПРИЙНЯТТЯ УПРАВЛІНСЬКИХ РІШЕНЬ ЩОДО ОРГАНІЗАЦІЇ МЕДИЧНОГО ПОСТАЧАННЯ В ЗБРОЙНИХ СИЛАХ УКРАЇНИ
}

\author{
М. В. Білоус \\ Українська військово-медична академія, м. Київ, Україна
}

Вступ. 3 огляду на процес впровадження єдиної системи логістичного забезпечення Збройних Сил (ЗС) України, адаптованої до стандартів країн-членів НАТО, здійснення організації й управління медичним постачанням ЗС України з використанням новітніх інформаційних технологій для підвищення ефективності функціонування Медичних сил ЗС України стає вимогою сьогодення. Світова тенденція переходу до цифрових методів створення, передачі, обробки та зберігання інформації обумовила необхідність у впровадженні єдиної інформаційної системи для управління потоковими процесами у Медичних силах ЗС України. Водночас, слід виокремити виняткову роль аналітичних інформаційних систем, як засобу підтримки обгрунтованих управлінських рішень.

Мета. Дослідження можливостей використання інформаційної аналітичної системи «IBM i2 Analyst's Notebook» для підтримки прийняття управлінських рішень щодо організації медичного постачання в ЗС Украӥни.

Матеріали та методи. Для досягнення мети дослідження проведено аналіз закордонної $i$ вітчизняної наукової літератури, чинної нормативно-правової бази України, наказів Міністерства оборони України, Генерального штабу ЗС України, командувача Медичних сил ЗС України, а також зведена інформація, щодо потреби у лікарських засобах ЗС Украӥни та документація користувача аналітичної системи «IBM i2 Analyst's Notebook». Методами дослідження $\epsilon$ бібліографічний, аналітичний, прогностичний та узагальнення.

Результати. Проведений аналіз літературних джерел, а також вивчення документації користувача аналітичної системи «IBM i2 Analyst's Notebook» (інструкції з використання) спонукали дослідити можливості застосування вказаної системи для підтримки прийняття управлінських рішень щодо організації медичного постачання ЗС України у КМС ЗС України. Отримано наглядні приклади використання аналітичної системи «IBM i2 Analyst's Notebook», графічно зображені за допомогою можливостей програмного аналітичного забезпечення. Результати дослідження та відсутність альтернативних інформаційних аналітичних систем в Управлінні медичного постачання КМС ЗС України для оптимізації організації постачання медичної техніки та майна ЗС України стали основою розробки рекомендацій щодо впровадження вказаної ліщензійної інформаційної аналітичної системи для використання в органі управління Медичними силами. Це забезпечить мінімізацію логістичних витрат за рахунок гнучкого управління постачанням медичним майном військових частин ЗС Украӥни та закладів охорони здоров'я Міністерства оборони України на підставі створених аналітичних звітів.

Висновки. На основі аналізу літературних наукових джерел обгрунтовано оптимальний вибір аналітичної системи щодо організації медичного постачання ЗС України. Здійснено короткий опис аналітичної системи «IBM i2 Analyst's Notebook» ma досліджено можливості використання цієї інформаційної аналітичної системи для підтримки прийняття управлінських рішень з організації медичного постачання в Управлінні медичного постачання КМС ЗС України. Розроблено рекомендації щодо доцільності та практичного застосування цієї аналітичної системи для оптимізації управління постачанням медичною технікою та майном військових частин ЗС України та закладів охорони здоров'я МО України.

Ключові слова: інформаційна аналітична система, система медичного постачання, Медичні сили Збройних Сил України.

Вступ. Організація постачання медичної техніки та майна військовим частинам та закладам охорони здоров'я Збройних Сил (3С) України на сьогодні здійснюється відповідно діючих нормативно-правових актів, що регламентують забезпечення військ (сил) медичним майном $[1,2]$ та має свою специфіку. Причинами цьому $\epsilon$ обмежений термін зберігання, висока чутливість до умов зберігання та транспортування медичного майна.

Командуванню Медичних сил (КМС) 3С України для координації та визначення пріоритетності логістичного забезпечення медичним майном військових частин i закладів охорони здоров'я МО України потрібні дані щодо наявності й потреби у медичному майні. Для того, щоб ефективно 
управляти динамічною системою медичного постачання, необхідно в будь-який момент часу мати інформацію про наявність, детальний асортимент і стан матеріальних потоків медичної техніки та майна на будьякій стадії логістичного процесу. У зв'язку з цим, для оперативного прийняття обгрунтованих управлінських рішень на основі великого обсягу даних і забезпечення можливості швидко реагувати на зміну ситуації та знаходити причини таких змін, необхідні інформаційні аналітичні інструменти або програми підтримки прийняття рішень. Вони надають широкі можливості щодо аналізу даних 3 метою оптимізації управління логістичними процесами в системі медичного постачання $3 \mathrm{C}$ України [3].

Аналіз наукових досліджень і публікацій, в яких започатковано вивчення даної проблеми свідчить про те, що багато вчених, як вітчизняних, так і зарубіжних, присвятили свої праці розробці методологічних основ щодо створення та впровадження автоматизованої системи управління логістичним забезпеченням у збройні сили, а також інформаційної складової державного управління у сфері безпеки і оборони. Вказану проблематику у своїх працях висвітлювали, зокрема, такі вітчизняні вчені: В. Ф. Педан, В. В. Беляченко, О. А. Романченко (2018) [4], I. В. Павловський, В. В. Твердохлібов, О.М. Башкиров (2017) [5], А. В. Зозуля (2017) [6], 0. Г. Бондаренко, Л. Ф. Товма, Р. В. Нестеренко, О. Г. Касім (2018) [7], І. Ю. Гаврилюк, О. Й. Мацько, В. О. Дачковський (2019) [8], а також зарубіжні науковці: M. Pecina, Vlachová H., R. Dufek, Husak J, (2010-2018) [9-11], Szabados Janos Jozsef (2018) [12], Moshe Kress (2016) [13] та інші. Крім того, розгляд питання використання інформаційної системи логістики LOGFAS у 3 C України здійснювався в окремих публікаціях I. Ю. Гаврилюка, М. Ю. Степанюка, І. П. Сініцина, О. В. Котелі та інших (2018-2019) $[14,15]$.

Водночас, проведений аналіз показав, що науковцями досліджено різні аспекти вказаної проблеми, проте без належної уваги залишається система медичного постачання 3С України у контексті впровадження інформатизації логістичних процесів. Разом із тим, до теперішнього часу не були вивчені можливості використання аналітичних інструментів для підтримки прийняття управлінських рішень щодо організації медичного постачання ЗС України в Управління медичного постачання КМС ЗС
України.

Зважаючи на вищевикладене, проблема впровадження аналітичної програми підтримки прийняття рішень для потреб Медичних сил 3С України щодо реалізації ефективного управління потоковими процесами у системі медичного постачання та набуття функціональної сумісності у спільних медичних місіях Альянсу й активне співробітництво зі збройними силами державчленів НАТО $\epsilon$ актуальною та потребує детального вивчення.

\section{Мета роботи. Дослідження} можливостей використання інформаційної аналітичної системи «IBM i2 Analyst's Notebook» для підтримки прийняття управлінських рішень щодо організації медичного постачання ЗС України в Управлінні медичного постачання КМС ЗС України.

Матеріали та методи дослідження. Для досягнення мети дослідження проведено аналіз закордонної і вітчизняної наукової літератури, чинної нормативно-правової бази України, наказів Міністерства оборони України, Генерального штабу ЗС України, командувача Медичних сил 3С України, а також зведена інформація, щодо потреби у лікарських засобах 3С України та документація користувача (інструкції 3 використання) аналітичної системи «IBM i2 Analyst's Notebook». Методами дослідження $€$ бібліографічний, аналітичний, прогностичний та узагальнення.

Результати дослідження та їх обговорення. Реформи щодо порядку забезпечення медичним майном військових частин та закладів охорони здоров'я 3С України на мирний час обумовили зміни підходів та методів управління у системі медичного постачання, а також впровадження новітніх інформаційних технологій для підвищення ефективності функціонування Медичних сил $3 \mathrm{C}$ України. Попередні дослідження показали відсутність в Управлінні медичного постачання органу управління медичною службою 3С України інформаційних аналітичних систем [16], що і стало передумовою у визначенні оптимального вибору аналітичної системи для потреб Командування Медичних сил 3 С України щодо організації медичного постачання $3 \mathrm{C}$ України. Вищезазначена система забезпечить підтримку прийняття управлінських рішень щодо медичного постачання військових частин ЗС України та 
закладів охорони здоров'я МО України.

Аналіз наукових літературних джерел [17-20] показав певні переваги аналітичного програмного забезпечення «IBM i2 Analyst's Notebook». Так, авторами зазначено, що вказана аналітична система фактично $\epsilon$ міжнародним стандартом для проведення аналітичних досліджень. Технологія, яка запропонована компанією «IBM i2 Limited», визнана користувачами більш ніж тисячі організацій 70-ти країн, у тому числі: НАТО, ОOH, Інтерполом, Європолом. Інтеграційні рішення «IBM i2» дозволяють об'єднувати бази даних, які вже накопичені і розміщені за різними вкладками, здійснювати аналіз без додаткового завантаження, конвертації та перемикання між завданнями. IBM i2 забезпечує з'єднання з такими реляційними базами даних, як Oracle, Microsoft SQL Server, Microsoft Access, a також має можливість взаємодіяти з ГІС-програмами (Географічноінформаційні системи), статистичними інструментами аналізу [18].

Аналітичні технології «ІВМ і2» $\epsilon$ комплексним інтелектуальним інструментарієм для багатовимірного аналізу. Залежно від глобальності та сфери застосування можуть використовуватися деякі його складові [17]. Зокрема, «IBM i2 Analyst's Notebook» - візуальне аналітичне середовище, яке дозволяє максимально ефективно використовувати величезні обсяги інформації. Завдяки інтуїтивно зрозумілому інтерфейсу з урахуванням контексту дозволяє аналітикам швидко зіставляти, аналізувати і наочно представляти дані 3 різних джерел, скорочуючи час на пошук важливої інформації в складних даних [17]. «IBM i2 Analyst's Notebook» надає актуальні та дієві аналітичні засоби, що допомагають оптимізувати в тому числі і логістичні процеси.

3 точки зору логістичного підходу, вказана аналітична система допомагає певним підрозділам вирішувати такі завдання: швидко систематизувати розрізнені дані в єдиному узгодженому поданні; визначати ключові логістичні вузли, логістичні процеси, їх зв'язки та закономірності, які не завжди можна виявити іншими засобами; покращувати розуміння структури, ієрархії логістичної мережі; спрощувати обмін складними даними, що дозволяє приймати своєчасні та точні оперативні рішення; надає можливість здійснювати продуктивну аналітичну роботу, завдяки надійним рішенням для візуалізацій аналітичних результатів.

У зв'язку 3 вищевикладеним та відсутністю альтернативних інформаційних аналітичних систем в Управлінні медичного постачання КМС ЗС України, вважаємо за доцільне дослідити можливості використання «IBM i2 Analyst's Notebook» для оптимізації управління потоковими процесами в логістичній мережі медичного постачання 3 С України.

У ході проведених досліджень отримано аналітичні звіти, графічно зображенні за допомогою можливостей програмного аналітичного забезпечення, частина яких наведена на рис. 1 та рис. 2, що ілюструють застосування аналітичної системи «IBM i2 Analyst's Notebook» для потреб Управління медичного постачання КМС 3С України. Це програмне забезпечення дозволяє здійснювати ефективний збір, обробку та використання аналітичної інформації щодо функціонування системи медичного постачання ЗС України. Зокрема, відображення потреби ВМКЦ регіонів (контрагентів) у певному лікарському засобі за роками, відображення потреби та загальної суми закупленого медичного майна у певний період часу, загальної суми поставки та основних контрагентів, відображення періодичності закупівлі медичного майна 3 ціною за одиницю, графік (за роками) закупівлі медичного майна із зазначенням ціни та контрагентів, «теплову карту» із порівнянням загальних сум, витрачених контрагентом на закупівлю певного лікарського засобу. Проте, цей перелік щодо можливостей аналітичної системи «IBM i2 Analyst's Notebook» далеко не вичерпаний, що підтверджує детальне вивчення документації користувача «IBM i2 Analyst's Notebook».

Таким чином, отримані результати свідчать про доцільність використання цієї аналітичної системи для мінімізації логістичних витрат за рахунок гнучкого управління логістичними ресурсами на підставі створених аналітичних звітів.

Враховуючи

вищезазначене, рекомендуємо впровадити вказану ліцензійну інформаційну аналітичну систему для використання в КМС ЗС України для:

проведення аудиту підпорядкованих закладів охорони здоров'я;

узагальнення даних щодо проведення закупівлі медичного майна підрозділами медичного постачання ЗС України; . 


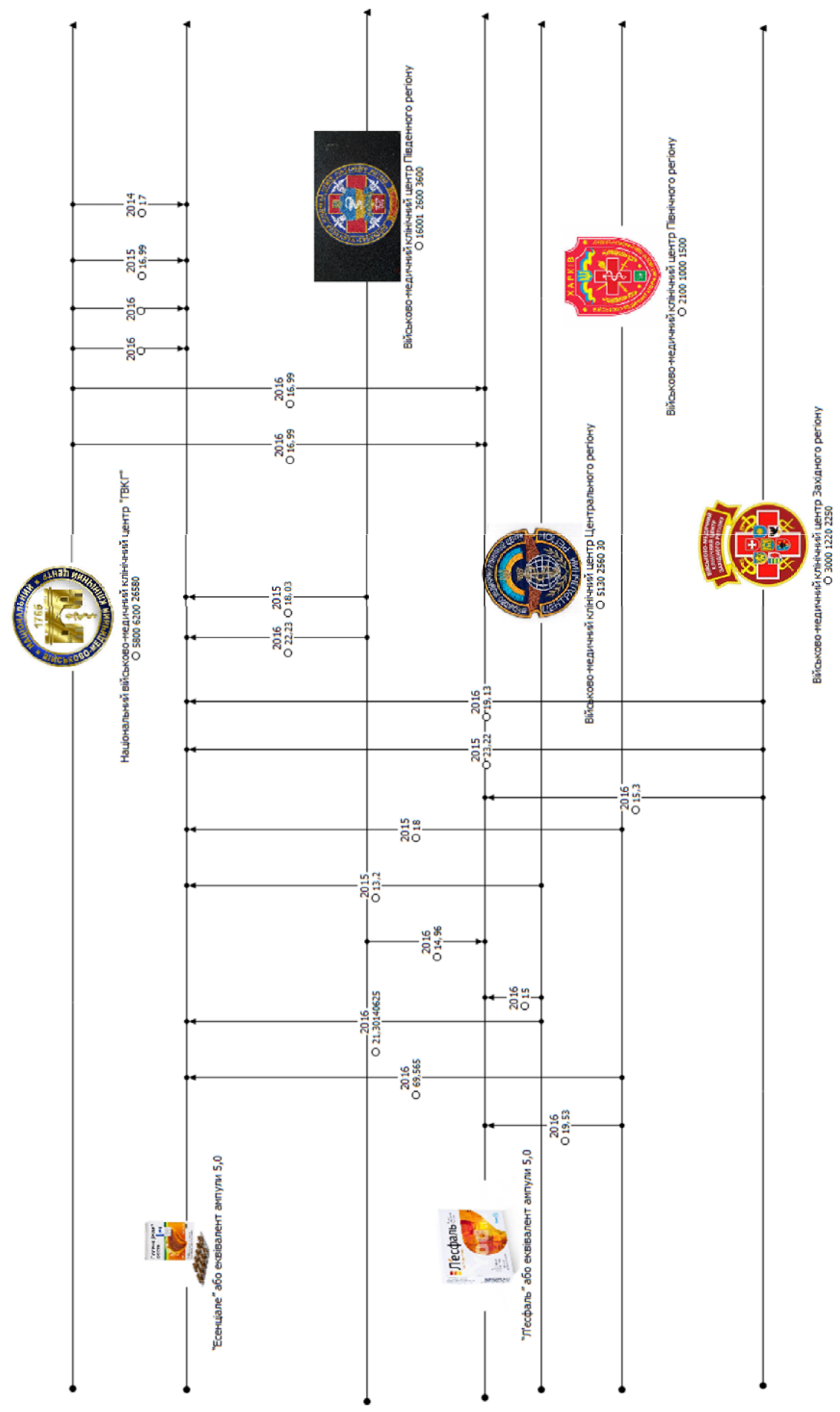

Рисунок 1. Відображення періодичності закупівель ВМКЦ (ціна за одиницю). 


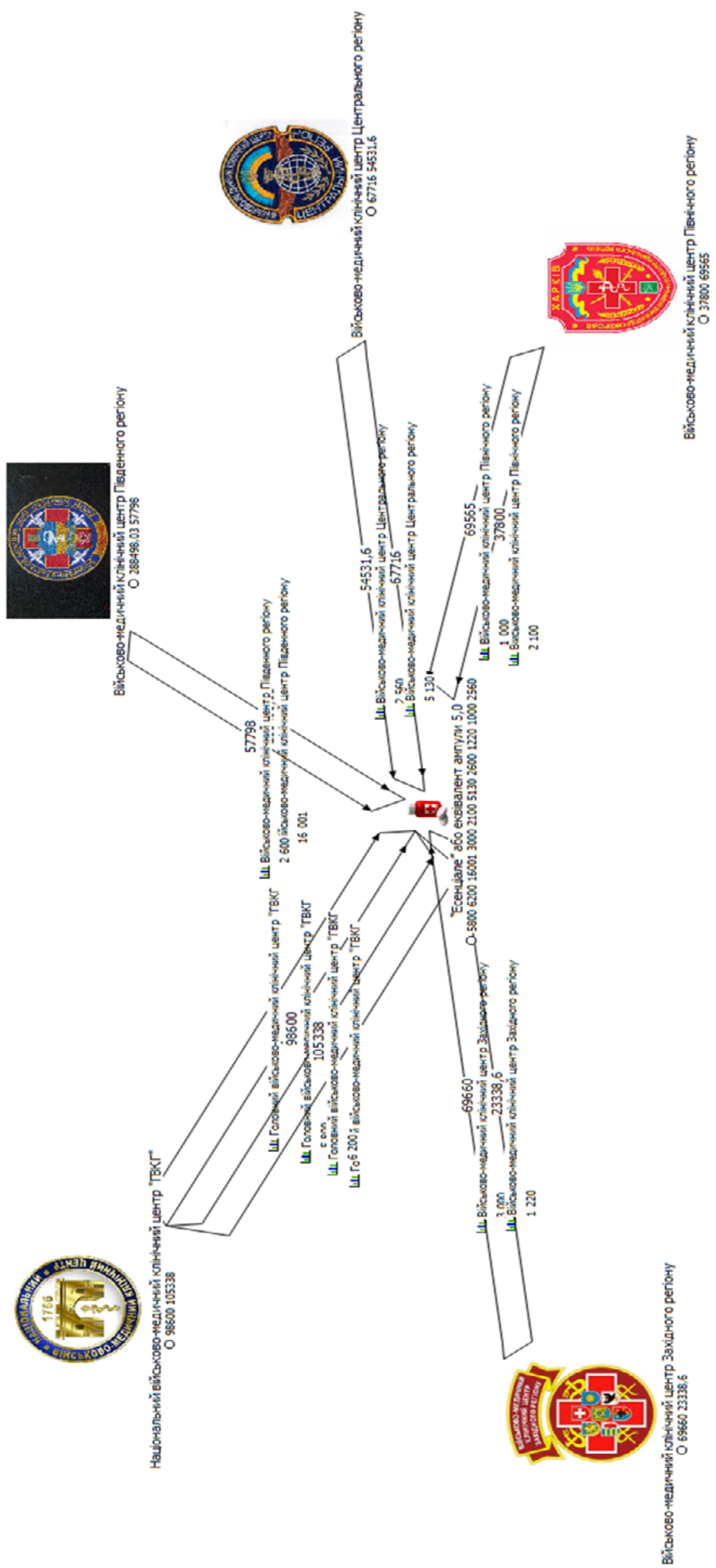

Рисунок 2. Відображення потреби у лікарському засобі, загальної суми поставки та основних контрагентів. 
узагальнення даних щодо потреби та наявності медичного майна у 3С України.

Перспективи

подальших

досліджень. Вбачаємо у подальших наукових дослідженнях актуальних питань щодо впровадження сучасної інформаційної системи для керування процесами обліку та передачі інформації щодо постачання

\section{Висновки}

1. На основі аналізу літературних наукових джерел обгрунтовано оптимальний вибір аналітичної системи для організації медичного постачання в 3С України.

2. Здійснено короткий опис аналітичної системи «IBM i2 Analyst's Notebook» та досліджено можливості використання цієї інформаційної аналітичної системи для підтримки прийняття управлінських рішень 3

\section{Література}

1. Про затвердження Керівництва з організації постачання медичною технікою та майном Збройних Сил України у мирний час: наказ Директора Військово-медичного департаменту Міністерства оборони України від 12.12.2016 № 36. URL: http://www.mil.gov.ua

2. Про затвердження Порядку постачання медичного майна Збройним Силам України в мирний час: наказ МОУ від 11.05.2017 р. № 261. URL: https://zakon.rada.gov.ua/laws/show/z0688-17

3. Білоус М.В. Науково-практичні підходи до логістичного забезпечення медичним майном Збройних Сил України у контексті інформаційної логістики: науково-метод. рекомендації за загальною редакцією проф. Шматенка О.П.та проф. Рижова О.А. Київ, 2020. 84 с.

4. Беляченко В.В., Педан Ф.Ф., Романченко О.А. Підходи до створення, підтримки і вдосконалення АСУ логістичного забезпечення 3С України 3 урахуванням досвіду країн-членів НАТО. Збірник наукових праць Центру воєнно-стратегічних досліджень НУОУ ім. Івана Черняховського. 2018. № 3(64). URL: http://znpcvsd.nuou.org.ua/article/view/177510/177369

5. Павловський I.В., Твердохлібов В.В., Башкиров О.М. Пропозиції щодо удосконалення системи логістичного забезпечення Збройних Сил України. Озброєння та військова техніка. 2017. № 1 (13). С. 50-54.

6. Зозуля А.В. Аналіз специфіки використання інновацій у логістичних процесах тилового забезпечення підрозділів Національної гвардії України. ScienceRise. 2017. № 11 (40). C15-17.

7. Бондаренко О.Г., Товма Л.Ф., НестеренкоР.В. Основні положення щодо логістичного забезпечення Національної гвардії України. Вісник економіки транспорту і промисловості. 2018. № 61. C. $230-240$.

URL: https://doi.org/10.18664/338.47:338.45.v0i61.12787 $\underline{94 .}$ медичного майна закладам та підрозділам медичного постачання 3С України. На наш погляд, вона має бути єдиною, уніфікованою, надійною і поширеною на орган управління Медичними силами та на заклади і підрозділи медичного постачання ЗС України.

організації медичного постачання в Управлінні медичного постачання КМС ЗС України.

3. Розроблено рекомендації щодо доцільності та практичного застосування цієї аналітичної системи для оптимізації управління постачанням медичною технікою та майном військових частин та закладів охорони здоров'я ЗС України.

8. Гаврилюк І.Ю., Мацько О.Й., Дачковський В.О. Концептуальні основи управління потоками в системі логістичного забезпечення Збройних Сил України. Сучасні інформаційні технології у сфері безпеки та оборони. 2019. №1 (34). C. 37-44. URL: https://doi.org/10.33099/2311-7249/2019-34-1-37$\underline{44}$

9. Pecina M., Vlachová H. Automated Support «Logassessrep». The Knowledge - Based Organization: The 16 th International Conference. Sibiu, Romania, 2527 November 2010.

10.Pecina M., Dufek R. Use of LOGFAS tools inlogistics planning in NATO. URL: http://www.armyacademy.ro/reviste/rev2 2016/Pec ina.pdf

11. Pecina M., Husak J. Application of the NewNato Logistics System. Land Forces AcademyReview. Sibiu. 2018. N 2. P. 121-127.

12.Szabados J.J. A logisztikai információs rendszer szükségessége és fejlesztési lehetőségei a Magyar Honvédségben. HSz Logisztika. 2018. № 4. P.89-102. URL:https://honvedelem.hu/files/files/111397/hsz_2 018_4_beliv_089_102.pdf

13. Kress M. Operational Logistics. The Art and Science of Sustaining Military Operations. Second Edition. Springer International Publishing Switzerland. $2016 . \quad$ URL: https://www.springer.com/gp/book/978331922673 6.

14.Степанюк М.Ю., Сініцин І.П., Котеля О.В. Проблема створення інформаційної системи логістикив Збройних Силах України, що відповідає стандартам НАТО. Проблеми програмування. 2018.

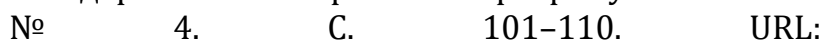
https://doi.org/10.15407/pp2018.04.101

15. Гаврилюк І.Ю., Мацько О.Й., Дачковський В.О. Концептуальні основи управління потоками в системі логістичного забезпечення Збройних Сил України. Сучасні інформаційні технології у сфері безпеки та оборони. 2019. №1 (34). C. 37-44. URL: 
https://doi.org/10.33099/2311-7249/2019-34-1-37$\underline{44}$

16.Білоус М.В. Рижов О.А., Шматенко О.П. Вивчення стану готовності закладів та підрозділів медичного постачання Збройних Сил України до впровадження інформаційної системи логістики. Фармацевтичний журнал. 2020. № 4. С. 39-48.

17. Стоянов I.I. Інтерактивний посібник IBM i2 Analyst's Notebook 9

18.Кирєєва О. Використання альтернативних аналітичних інструментів у кримінальному аналізі. Збірник наукових праць Національної академії Державної прикордонної служби України. Серія: Військові та технічні науки. 2016. № 4(70). С. 64-76.

19.Тишлек Д.П., Мазур Ю.В. Використання програмного забезпечення IBM i2 analyst's notebook

\section{Referenses}

1. Pro zatverdzhennya Kerivnytstva z orhanizatsiyi postachannya medychnoyu tekhnikoyu ta maynom Zbroynykh Syl Ukrayiny u myrnyy chas: nakaz Dyrektora Viys'kovo-medychnoho departamentu Ministerstva oborony Ukrayiny vid 12.12.2016 № 36 . http://www.mil.gov.ua

2. Pro zatverdzhennya Poryadku postachannya medychnoho mayna Zbroynym Sylam Ukrayiny $\mathrm{v}$ myrnyy chas: nakaz MOU vid 11.05.2017 r. № 261. https://zakon.rada.gov.ua/laws/show/z068817

3. Bilous, M.V. (2020) Naukovo-praktychni pidkhody do lohistychnoho zabezpechennya medychnym maynom Zbroynykh Syl Ukrayiny u konteksti informatsiynoyi lohistyky: naukovo-metod. rekomendatsiyi za zahal'noyu redaktsiyeyu prof. Shmatenka O.P. ta prof. Ryzhova O.A. Kyyiv. 84 s.

4. Belyachenko, V.V., Pedan, F.F., Romanchenko, O.A. (2018) Pidkhody do stvorennya, pidtrymky i vdoskonalennya ASU lohistychnoho zabezpechennya ZS Ukrayiny z urakhuvannyam dosvidu krayin-chleniv NATO. Zbirnyk naukovykh prats' Tsentru voyennostratehichnykh doslidzhen' NUOU im. Ivana Chernyakhovs'koho. № 3(64). http://znpcvsd.nuou.org.ua/article/view/177510/177369

5. Pavlovs'kyy, I.V., Tverdokhlibov, V.V., Bashkyrov, O.M. (2017) Propozytsiyi shchodo udoskonalennya systemy lohistychnoho zabezpechennya Zbroynykh Syl Ukrayiny. Ozbroyennya ta viys'kova tekhnika. № 1 (13). 50-54.

6. Zozulya, A.V. (2017) Analiz spetsyfiky vykorystannya innovatsiy u lohistychnykh protsesakh tylovoho zabezpechennya pidrozdiliv Natsional'noyi hvardiyi Ukrayiny. ScienceRise. № 11 (40). 15-17.

7. Bondarenko, O.H., Tovma, L.F., NesterenkoR.V. (2018) Osnovni polozhennya shchodo lohistychnoho zabezpechennya Natsional'noyi hvardiyi Ukrayiny. Visnyk ekonomiky transportu i promyslovosti. № 61 . 230-240.

https://doi.org/10.18664/338.47:338.45.v0i61.12787 94.

8. Havrylyuk, I.Yu., Mats'ko, O.Y., Dachkovs'kyy V.O. (2019) Kontseptual'ni osnovy upravlinnya potokamy v systemi lohistychnoho zabezpechennya Zbroynykh Syl Ukrayiny. Suchasni informatsiyni tekhnolohiyi u sferi у аналітичній діяльності. Використання сучасних інформаційних технологій діяльності національної поліції України: матеріали всеукраїнського наук.практ. семінару, м. Дніпро, 24 листопада 2017 року. Дніпро: ДДУВС, 2017. С. 15-19.

20.Сеник В.В., Шишко В.Й., Магеровська Т.В. Сучасні технології аналізу у діяльності правоохоронних органів. Інформаційно-аналітичне забезпечення діяльності підрозділів кримінальної поліції: збірник наукових статей за матеріалами доповідей Всеукраїнської науково-практичного семінару 23 березня 2018 року / упорядники А.В. Баб'як, В.В. Сеник, Т. В. Магеровська. Львів: ЛьвДУВС, 2018. С. 155-161

bezpeky ta oborony. №1 (34). 37-44. https://doi.org/10.33099/2311-7249/2019-34-1-37$\underline{44}$

9. Pecina, M., Vlachová, H. (2010) Automated Support «Logassessrep». The Knowledge - Based Organization: The 16 th International Conference. Sibiu, Romania, 25-27 November.

10. Pecina, M., Dufek, R. (2016) Use of LOGFAS tools inlogistics planning in NATO. http://www.armyacademy.ro/reviste/rev2 2016/Pec ina.pdf

11. Pecina, M., Husak, J. (2018) Application of the NewNato Logistics System. Land Forces AcademyReview. Sibiu. N 2. P. 121-127.

12.Szabados, J.J. (2018) A logisztikai információs rendszer szükségessége és fejlesztési lehetőségei a Magyar Honvédségben. HSz Logisztika. № 4. P.89-102. https://honvedelem.hu/files/files/111397/hsz 2018 4 beliv 089 102.pdf

13. Kress, M. (2016) Operational Logistics. The Art and Science of Sustaining Military Operations. Second Edition. Springer International Publishing Switzerland. https://www.springer.com/gp/book/978331922673 6.

14.Stepanyuk, M.Yu., Sinitsyn, I.P., Kotelya, O.V. (2018) Problema stvorennya informatsiynoyi systemy lohistykyv Zbroynykh Sylakh Ukrayiny, shcho vidpovidaye standartam NATO. Problemy prohramuvannya. № 4. 101-110.

15. Havrylyuk, I.Yu., Mats'ko, O.Y., Dachkovs'kyy V.O. (2019) Kontseptual'ni osnovy upravlinnya potokamy v systemi lohistychnoho zabezpechennya Zbroynykh Syl Ukrayiny. Suchasni informatsiyni tekhnolohiyi u sferi bezpeky ta oborony. №1 (34). 37-44.

16. Bilous, M.V. Ryzhov, O.A., Shmatenko, O.P. (2020) Vyvchennya stanu hotovnosti zakladiv ta pidrozdiliv medychnoho postachannya Zbroynykh Syl Ukrayiny do vprovadzhennya informatsiynoyi systemy lohistyky. Farmatsevtychnyy zhurnal. № 4. 39-48.

17. Stoyanov, I.I. Interaktyvnyy posibnyk IBM i2 Analyst"s Notebook 9

18. Kyryeyeva, 0. (2016) Vykorystannya al'ternatyvnykh analitychnykh instrumentiv $\mathrm{u}$ kryminal'nomu analizi. Zbirnyk naukovykh prats' Natsional'noyi akademiyi Derzhavnoyi prykordonnoyi 
sluzhby Ukrayiny. Seriya: Viys'kovi ta tekhnichni nauky. № 4(70). 64-76.

19. Tyshlek, D.P., Mazur YU.V. (2017) Vykorystannya prohramnoho zabezpechennya IBM i2 analyst's notebook $u$ analitychniy diyal'nosti. Vykorystannya suchasnykh informatsiynykh tekhnolohiy diyal'nosti natsional'noyi politsiyi Ukrayiny: materialy vseukrayins'koho nauk.-prakt. seminaru, m. Dnipro, 24 lystopada 2017 roku. Dnipro: DDUVS. 15-19.
20.Cenyk, V.V., Shyshko, V.Y., Maherovs'ka, T.V. (2018) Suchasni tekhnolohiyi analizu u diyal'nosti pravookhoronnykh orhaniv. Informatsiynoanalitychne zabezpechennya diyal'nosti pidrozdiliv kryminal'noyi politsiyi: zbirnyk naukovykh statey za materialamy dopovidey Vseukrayins'koyi naukovopraktychnoho seminaru 23 bereznya 2018 roku / uporyadnyky A.V. Bab'yak, V.V. Senyk, T. V. Maherovs'ka. L'viv: L'vDUVS. 155-161.

\title{
ВОЗМОЖНОСТИ ИСПОЛЬЗОВАНИЯ АНАЛИТИЧЕСКИХ ИНСТРУМЕНТОВ ДЛЯ ПОДДЕРЖКИ ПРИНЯТИЯ УПРАВЛЕНЧЕСКИХ РЕШЕНИЙ ПО ОРГАНИЗАЦИИ МЕДИЦИНСКОГО СНАБЖЕНИЯ В ВООРУЖЁННЫХ СИЛАХ УКРАИНЫ
}

\author{
М. В. Белоус \\ Украинская военно-медицинская академия, г. Киев, Украина
}

Вступление. Учитывая процесс внедрения единой системы логистического обеспечения Вооружённых Сил (BC) Украины, адаптированной к стандартам стран-членов НАТО, осуществление организации и управления медицинским снабжением ВС Украины с использованием новейших информационных технологий для повышения эффективности функционирования Медицинских сил ВС Украины становится требованием сегодняшнего дня. Мировая тенденция перехода к цифровым методам создания, передачи, обработки и хранения информации обусловила необходимость во внедрении единой информационной системы для управления потоковыми процессами в Медицинских силах ВС Украины. В то же время, следует отметить исключительную роль аналитических информационных систем, как средств поддержки обоснованных управленческих решений.

Цель. Исследование возможностей применения информационной аналитической системы «IВМ і2 Analyst's Notebook» для поддержки принятия управленческих решений по организации медицинского снабжения Вооружённых Сил Украины в Управлении медицинского снабжения Командования Медицинских сил Вооружённых Сил Украины.

Материалы и методы. Для достижения цели исследования проведен анализ зарубежной и отечественной научной литературы, действующей нормативно-правовой базы Украины, приказов Министерства обороны Украины, Генерального штаба ВС Украины, командующего Медицинских сил ВС Украины, а также сводная информация о необходимости в лекарственных средствах ВС Украины и документация пользователя аналитической системы «IBM i2 Analyst's Notebook». Методами исследования являются библиографический, аналитический, прогностический и обобщения.

Результаты. Проведенный анализ литературных источников, а также изучение документация пользователя аналитической системы «IBM i2 Analyst's Notebook» (инструкции по использованию) побудили исследовать возможности применения указанной системы для поддержки принятия управленческих решений по организации медицинского снабжения ВС Украины. Получены наглядные примеры использования аналитической системы «IBM i2 Analyst's Notebook», графически изображённые с помощью возможностей программного аналитического обеспечения. Результаты исследования и отсутствие альтернативных информационных аналитических систем в Управлении медицинского снабжения КМС ВС Украины для оптимизации организации снабжения медицинской техникой и имуществом ВС Украины стали основой разработки рекомендаций по внедрению указанной лицензионной информационной аналитической системы для использования в органе управления Медицинскими силами. Это обеспечит минимизацию логистических издержек за счёт гибкого управления снабжением медицинским имуществом воинских частей $B C$ Украины и учреждений здравоохранения ВС Украины на основании созданных аналитических отчётов.

Выводы. На основе анализа литературных научных источников обоснован оптимальный выбор аналитической системы по организации медищинского снабжения ВС Украины. Изложено краткое описание аналитической системы «IBM i2 Analyst's Notebook» и исследовано возможности применения этой информационной аналитической системы для поддержки принятия управленческих решений по организации медицинского снабжения ВС Украины. Разработаны рекомендации в целесообразности и практическом применении этой аналитической системы для оптимизации управления поставками медицинской техники и имущества воинским частям и учреждениям здравоохранения ВС Украины.

Ключевые слова: информационная аналитическая система, система медищинского снабжения, Медицинские силы Вооружённых Сил Украины. 


\title{
POSSIBILITIES OF USING ANALYTICAL TOOLS TO SUPPORT MANAGEMENT DECISIONS FOR THE ORGANIZATION OF MEDICAL SUPPLIES IN THE ARMED FORCES OF UKRAINE
}

\author{
M.V. Bilous
}

Ukrainian Military Medical Academy, Kyiv, Ukraine

Introduction. In view of implementation of the unified system of logistics support to the Armed Forces of Ukraine which is adapted to standards of NATO member countries, what is required now is procurement management for medical supplies to the Armed Forces of Ukraine based on the state-of-art information technologies in order to enhance performance of the Medical Forces of the Armed Forces of Ukraine. The world trend towards transition to digital creation, transmission, processing and storage of information has made it necessary to implement the unified information system to manage flow processes in the Medical Forces of the Armed Forces of Ukraine. At the same time, analytical information systems play a crucial role in supporting the substantiated managerial decisions.

Purpose. This work is aiming in study of potential for use of IBM i2 Analyst's Notebook information analytical system to support management decisions for the organization of medical supplies in the Armed Forces of Ukraine.

Materials and Methods. To achieve the research aim, foreign and domestic scientific literature, current regulatory and legal framework of Ukraine, orders of the Ministry of Defense of Ukraine and of the Head of the Medical Forces of the Armed Forces of Ukraine, as well as summary information on the demand for medicines by the Armed Forces of Ukraine were analyzed. Research methods were bibliographic, analytical, prognostic methods and generalization.

Results. The references review and exploring IBM i2 Analyst's Notebook analytical system capability necessitated to study of potential for use of this system to support managerial decisions by the Medical Forces Command taken for medical supplies to the Armed Forces of Ukraine. Recommendations are based on the findings obtained allowing for the lack of alternative information analytical systems for management of medical supplies in the Medical Forces Command of the Armed Forces of Ukraine and aimed at implementation of the above licensed information analytical system to use by the management body of the Medical Forces. It will enhance efficiency, quality and transparency of functioning of the Medical Forces of the Armed Forces of Ukraine. In addition, it will minimize logistical costs due to flexible management of medical stock supplies to military units and medicsl treatment facilities of the Armed Forces of Ukraine on the basis of generated analytical reports.

Conclusions. Based on review of scientific literature references, it was determined the optimal analytical system to be chosen for demands of the Medical Forces Command of the Armed Forces of Ukraine for management of medical supplies. The brief description of IBM i2 Analyst's Notebook analytical system was performed and potential of implementation of this information analytical system to support managerial decisions by the Medical Forces Command of the Armed Forces of Ukraine was studied. Practical recommendations for expediency of this analytical system use to optimize the management of medical supplies and equipment of military units nd medicsl treatment facilities of the Armed Forces of Ukraine were substantiated. of Ukraine.

Key words: information analytical system, medical supply system, the Medical Forces of the Armed Forces

\section{Відомості про автора:}

Білоус М.В. - доктор фармацевтичних наук, доцент, доцент кафедри військової фармації Української військово-медичної академії, м. Київ, Україна.

Email: maryvictory@ukr/net. ORCID: https://orcid.org/0000-0002-4370-8813.

Белоус М.В. - доктор фармацевтических наук, доцент, доцент кафедры военной фармации, Украинская военно-медицинская академия, г. Киев, Украина.

Bilous M. - Ph.D., DSc, Associate professor of the Department of Military Pharmacy, Ukrainian Military Medical Academy, Kyiv, Ukraine

E-mail: maryvictory@ukr.net. ORCID: https://orcid.org/0000-0002-4370-8813.

Адреса для листування: вул. Московська,45/1, буд.33, м. Київ 01015

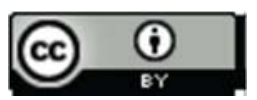

